\title{
Analisis kebutuhan perancangan aktivitas pembelajaran berdasarkan pada dimensi sikap moral bagi siswa sekolah dasar
}

\author{
Aulia Aenul Hayati a, 1*, Dina Pratiwi DS b, ${ }^{\text {be }}$ Ena Suhena Praja ${ }^{\text {c, } 3}$ \\ a Program Studi Pendidikan Guru Sekolah Dasar, Universitas Swadaya Gunung Jati, Cirebon, \\ Indonesia \\ ${ }^{1}$ auliyaaenul@fkip-unswagati.ac.id *; ${ }^{2}$ dinapratiwids@ @kip-unswagati.ac.id; \\ 3 enasp@fkip-unswagati.ac.id
}

*korespondensi penulis

\begin{tabular}{ll}
\hline \multicolumn{2}{l}{ Informasi artikel } \\
\hline Sejarah artikel: & \\
Diterima & $: 23-07-2018$ \\
Revisi & $: 08-02-2019$ \\
Dipublikasikan & $: 31-03-2019$ \\
\hline
\end{tabular}
ABSTRAK

Pergeseran nilai dan motivasi atas kelangsungan pendidikan yang disematkan pada sekolah dasar semakin menguat seiring dengan harapan tak terbatas dari para orang tua dalam menjamin kualitas kepribadian sang anak. Pada praktiknya, permasalahan yang muncul bagaimana

\section{Kata kunci:}

Aktivitas pembelajaran

Nilai moral

Sikap moral

Karakter

Sekolah dasar sekolah mampu menjawab berbagai tantangan yang disuguhkan dalam membentuk karakter disamping menjadikan siswa sebagai seseorang yang cerdas secara akademisi. Penelitian ini berupaya menganalisis kebutuhan atas perancangan aktivitas-aktivitas pembelajaran berdasarkan pada pengembangan sikap moral atau moral feeling siswa sebagai jawaban dan solusi dari permasalahan yang dikemukakan sebelumnya. Metode penelitian fokus pada $R \& D$ tahap pertama dari pola ADDIE. Hasil penelitian menunjukkan bahwa konsep moralitas pada pola pembelajaran siswa kelas V SDN Sunyaragi 2 relatif lebih memunculkan sisi moral knowing dengan pemaknaan sikap moral (moral feeling) yang hanya sebatas pada lapisan permukaan, tidak secara mendalam dan terstruktur. Dengan demikian, dibutuhkan sebuah perancangan aktivitas pembelajaran yang dapat mengakomodasi perkembangan dimensi moral feeling siswa dalam kaitannya dengan penguatan karakter positif yang idealnya dimiliki oleh siswa sebagai sumber daya manusia unggul.

\section{Keywords:}

Learning activities,

Moral value,

Moral feeling,

Character,

Elementary school

\begin{abstract}
The shift in values and motivation for the continuity of education embedded in Elementary Schools is getting stronger along with the infinite expectations of parents in ensuring the quality of the child's personality. In practice, new problems arise surface is how schools are able to answer the challenges presented in shaping the character in addition to making students as someone who is smart academically. This research seeks to analyze the need for the design of learning activities based on the development of moral attitude or moral feeling of the students as the answer and solution of the problems presented earlier. Research method is $R \& D$ with ADDIE model. The results showed that the concept of morality on the pattern of learning grade V SDN Sunyaragi 2 relatively more led to the moral side knowing with the meaning of moral feeling (moral feeling) which is only limited to the surface layer, not in depth and structured. Thus, it takes a design of learning activities that can accommodate the development of students' moral sense dimensions in relation to the reinforcement of positive characters ideally possessed by students as excellent human resources.
\end{abstract}

\section{Pendahuluan}

Fitrah pendidikan memiliki korelasi kuat dengan tuntutan dan kebutuhan bangsa
Indonesia dalam melahirkan warga negara berkarakter cerdas, produktif - dinamis serta memiliki jati diri yang kukuh. Sebagai upaya 
pencapaian target tersebut maka diperlukan banyak pilihan pendekatan yang lebih dapat menyentuh esensi nilai moralitas dari suatu konsep keilmuan di samping pencapaian dalam nilai akademik secara khusus, yakni bagaimana pendidikan dapat memberikan kesempatan penuh kepada peserta didik untuk dapat mengeksplorasi dan mengembangkan karakter secara maksimal dengan tetap memperhatikan faktor heterogenitas kecerdasan majemuk yang inheren dimiliki oleh setiap individu. Maka pada saat yang bersamaan pengetahuan akan suatu keilmuan menjadi penyokong yang tidak kalah penting pula. Pada titik tersebut fungsi pendidikan dengan sendirinya akan menjadi kukuh menempati urutan pertama dalam upaya memajukan bangsa.

Pada perkembangannya, tantangan dan peluang pendidikan dalam mengupayakan perbaikan kualitas sumber daya manusia sejak usia Sekolah Dasar dilekatkan pada program penguatan pendidikan karakter yang tidak hanya dibebankan pada satu titik lingkungan sekolah sebagai poin sentral. Lebih dari itu, dalam menangani peserta didik sebagai manusia yang juga memiliki keinginan dan kebutuhan dasar diperlukan kehadiran dan peran beberapa lingkungan primer lainnya. keefektifan pendidikan karakter ideal turut ditentukan pula oleh nilai dasar karakter budaya sekolah, keluarga, dan masyarakat, integrasi program kurikuler dan ekstrakurikuler, teladan pendidik bagi peserta didik, dan penggunaan situasi lingkungan budaya sekolah (Ruyadi, 2010) sebagaimana moralitas seseorang dapat tumbuh dari apa yang dialami secara langsung yang berkembang kemudian menjadi suatu kebiasaan (Komariah, 2011)

Beberapa kondisi menunjukkan bahwa, keberadaan tingkat interaksi antara pendidik dan peserta didik, dan pengetahuan yang diperoleh saling mempengaruhi dan dipengaruhi oleh keyakinan nilai moral bawaan dan nilai moral yang dibelajarkan terhadap sikap yang dapat terbentuk selanjutnya. Sebagaimana salah satu prinsip pedagogis yang menekankan keterkaitan antar sub sistem aktivitas, komunikasi, dan kepribadian (Danim, 2015). Hal ini berkaitan pula dengan komponen civic skill atau kecakapan warga negara. Salah satu butir dari civic skill tersebut adalah participatory skill atau kecakapan partisipatoris yang oleh Mujtahidin (2017, hal. 45) dijabarkan kembali menjadi "kecakapan berinteraksi (interacting), kecakapan memonitor atau memantau (monitoring), dan kecakapan mempengaruhi (influencing)".

Dengan demikian kerja sama antar aspek lingkungan hidup peserta didik menjadi penentu dominan tingkat keberhasilan pelaksanaan pendidikan karakter. Dengan demikian pendidik dan pembelajar idealnya harus memahami jika kebutuhan akan setiap ilmu memiliki muara akhir yaitu pada pencapaian tingkat kualitas diri. Hal ini mengindikasikan keutamaan pendidikan dalam membentuk smart and good citizenship.

Kesadaran akan pentingnya penanganan atas permasalahan ini menghantarkan para pendidik dan peneliti dalam mengkaji dan mengupayakan hal-hal terbaik seputar upaya penanganan permasalahan pendidikan yang disadurkan dengan keutamaan nilai moralitas yang diyakini berperan sebagai jawaban serta solusi yang paling tepat untuk dilaksanakan. Penelitian (Hayati, 2015) menyuguhkan permasalahan pada ranah pelaksanaan suatu program pendidikan yang dibaurkan dengan nilai moralitas dalam bentuk program Living Values Activities (LVA). Kemungkinan untuk terjadinya ketaksesuaian ilmu, pemahaman, dan karakter siswa dapat saja terjadi. Diketahui permasalahan umum yang terjadi yaitu dalam hal tidak sederhananya pengukuran keberhasilan penanaman nilai moral selain inkonsistensi aturan dan keterbatasan waktu pelaksanaan.

Indikasi utama berada pada keutamaan kajian korelasional dengan apa yang dinamakan degradasi nilai. Ketaksesuaian tujuan pendidikan yang menyertakan unsur moralitas secara bersamaan yaitu hadir dari ketidakberfungsian lembaga pendidikan sebagai pembentuk karakter siswa, dan juga dapat dipahami dari bagaimana dilaksanakannya sebuah praktik pendidikan (Ali, 2009). Penggambaran lebih jauh yaitu kultur masyarakat yang mudah terpengaruh 
oleh nilai budaya asing, lembaga pendidikan semata-mata menjalankan program tercanangkan pemerintah, ketidakjelasan konsep pendidikan nilai lembaga pendidikan, kualitas rendah para peserta didik karena kurang atensi dan monitoring pendidik, nilai moral bersifat abstrak, pendidikan gagal menyampaikan dan menanamkan (Subur, 2007; Wiyono, 2012).

Terdapat kekhawatiran yang beralasan ketika domain kognitif begitu superior di atas domain afektif dan psikomotor. Cita-cita pendidikan kian melaju sebanding dengan permasalahan pembelajaran sekolah dasar yang belum menemukan pola pembelajaran moralitas yang dinilai tepat. Dari sini terlihat apa yang sebenarnya sangat dibutuhkan oleh dunia pendidikan. Domain kognitif, afektif, dan psikomotor harus sama-sama menjadi luaran utuh dari suatu proses pembelajaran. Untuk mewujudkannya diperlukan upaya konkret dan manusiawi dimana nilai moral tidak berhenti hanya pada tataran konsepsi pengetahuan moral (moral knowing), lebih dari itu juga mampu diiternalisasi oleh para peserta didik melalui aktivitas pembelajaran berdasarkan nilai sikap yang bermoral (moral feeling). Sehingga analisis kebutuhan perancangan aktivitas berdasarkan perkembangan sosial dan moral tersebut penting untuk dilakukan demi menghindari kesalahan dalam menguraikan permasalahan serta kebutuhan peserta didik.

Digambarkan dalam strategi pembelajaran emosional, bahwa terdapat beberapa hal yang harus diperhatikan dan dilakukan oleh para guru terhadap peserta didik yaitu: (1) penciptaan suasana kondusif kelas secara emosional, (2) berlaku sebagai mentor, menyediakan ketulusan antusiasme emosional, (3). penanaman perilaku positif tanpa tekanan, (4) penemuan hasrat belajar, target capaian, dan pendukung upaya pencapaian yang dilakukan, (5). memberikan pembelajaran yang menyuguhkan daya tarik dan relevansi dengan pengetahuan dasar bawaan peserta didik, (6) kemampuan dalam menumbuhkan kenyamanan dalam kelas, (7) penciptaan kelas sebagai tempat saling memahami dan menghargai antar pendidik dan peserta didik, (8) kemampuan mengenali emosional peserta didik, (9) penyesuaian interaksi sebagaimana perbedaan kondisi emosional peserta $\operatorname{didik}($ Supriadi \& Darmawan, 2013).

Lebih jauh prinsip-prinsip pendidikan sebagaimana tertuang pada Undang-Undang No. 20 Tahun 2003 begitu menekankan aspek penyelenggaraan pendidikan secara demokratis, berkeadilan dan anti diskriminatif, menjunjung tinggi hak asasi manusia, nilai keagamaan, nilai kultural, dan kemajemukan bangsa dengan satu kesatuan yang sistematik dengan sistem terbuka dan multi makna. Pendidikan budi pekerti yang kaya akan nilai-nilai pada pelaksanaannya tidak hanya terikat pada pelajaran Pendidikan Kewarganegaraan saja. Lebih jauh dari itu, jenis pendidikan ini justru seringkali berperan sebagai hidden curriculum yang muatannya terintegrasi pada semua mata pelajaran tanpa kecuali, terlebih pada keilmuan pendidikan Sekolah Dasar.

Pendidikan sekolah dasar merupakan fondasi awal pembentukan karakter peserta didik. Dengan mengusung pembelajaran berbasis nilai moral maka banyaknya disiplin ilmu diharapkan dapat turut mengistimewakan kecerdasan-kecerdasan peserta didik yang heterogen. Sebagaimana model pengembangan moral kognitif sebagai bagian dari model pembelajaran berbasis nilai yang mengasah kemampuan peserta didik dalam menghadapi permasalahan dilema moral serta bagaimana cara mengambil keputusan terbaik terkait permasalahan tersebut (Mujtahidin, 2017).

Hal ini sejalan pula dengan konsep pendidikan nilai yang bertujuan untuk pembentuk nilai, aktualisasi sikap pencerminan nilai, dan bimbingan konsistensi nilai (Mulyana, 2004) sebagai suatu upaya memanusiakan manusia. Yaitu dimana seseorang akan "menjadi manusia" yang sesungguhnya ketika ia mampu menghadirkan diri yang berbudi, memiliki kehendak berbuat baik, yang meningkat pada kemampuan proses aktualisasi nilai pada diri pribadi di berbagai dimensi kehidupan sosial, merujuk pada pencapaian karakter warga negara yang partisipatif dan bertanggung jawab (Darmadi, 2010; Hayati, 2017) 
Pengetahuan dan keyakinan guru terhadap peserta didik bahwa setiap individu memiliki kecerdasan yang berbeda antara satu dengan lainnya memberikan kesempatan nilai-nilai moral untuk dapat menyuguhkan rasa nyaman dan percaya diri dalam mengembangkan bakat, potensi, dan sikap moralitas. Selanjutnya hal ini dapat mempermudah proses transformasi materi pembelajaran dalam bentuk internalisasi nilai yang diyakini. Pengelolaan sumber daya dan proses pembelajaran dilakukan untuk mendorong semangat belajar sepanjang hayat (Sanusi, 2016). Selain sorotan pada keutamaan kecerdasan majemuk, juga terdapat kajian-kajian lain sebagaimana keutamaan pengusungan dimensi karakter, keutamaan kebutuhan dan keinginan dasar peserta didik yang beragam, agresivitas peserta didik, kebutuhan akan pendidikan inklusi bagi anak berkebutuhan khusus dan konsep kreativitas peserta didik yang tanpa batas. Dengan demikian tujuan pendidikan berlaku sebagaimana ia disandingkan dengan teori psikoanalisis yang digagas oleh Sigmun Freud yaitu untuk mewujudkan manusia berkualitas baik secara akademik maupun secara sikap moralitas dengan cara pemberian tuntutan rinci mengenai bentuk proyeksi tujuan apa yang hendak dicapai dari suatu pendidikan, cara bagaimana tujuan tersebut dapat dicapai, dan tingkat kemajuan yang diperoleh oleh peserta didik (Helaluddin \& Syawal, S., 2018).

\section{Metode}

Penelitian ini merupakan bagian kecil dari desain Research and Development $(\mathrm{R} \&$ D) yang berperan dalam penelitian dan pengembangan pembelajaran berdasarkan sikap moral (moral feeling) melalui serangkaian tahapan penelitian dan uji hingga model dapat benar-benar diterapkan pada pembelajaran sekolah dasar. Model penelitian dan pengembangan ADDIE dipilih dengan pertimbangan ketermuatan karakteristik yang mampu mengakomodasi kepentingan penelitian dan pengembangan dalam bidang pendidikan terutama dalam model pembelajaran dengan tahapan-tahapannya yang meliputi analisis, desain, pengembangan, implementasi, dan evaluasi.

Tahap pertama yang dilaksanakan disajikan dalam bentuk hasil analisis masalah dan kebutuhan atas perancangan aktivitas pembelajaran berdasarkan pada dimensi moral feeling bagi siswa sekolah dasar yang dikaji dari gambaran kondisi pembelajaran yang berimbas pada kecenderungan penghayatan sikap moral siswa. Instrumen yang digunakan dalam penelitian ini yaitu instrumen tertulis melalui angket/ kuesioner, wawancara dan instrumen pengamatan melalui lembar observasi terhadap seluruh komponen kegiatan belajar mengajar Sekolah Dasar.

Pengolahan dan analisis data dilakukan berdasarkan data-data yang diperoleh selama penelitian berlangsung guna kemanfaatan pengembangan model pembelajaran baru disamping penyusunan laporan hasil penelitian. Sementara itu, pengkajian permasalahan dan kebutuhan atas suatu pembelajaran yang didasarkan pada sikap moral (moral feeling) melalui pembelajaran sekolah dasar disajikan dengan pembahasan keseluruhan hasil (1) pengolah dan analisis data berdasarkan pola kuantitatif angket /kuesioner dan (2) kualitatif deskriptif yang dikorelasikan dengan berbagai teori dari studi literatur dan penelitian terdahulu lainnya yang memiliki relevansi signifikan.

\section{Hasil dan Pembahasan}

Secara umum, mayoritas siswa dapat dikategorikan memiliki antusiasme yang tinggi terhadap kelangsungan pembelajaran. Hal ini menunjukkan pula tingkat kepemilikan pengetahuan moral (moral knowledge) peserta didik yang mumpuni. Dibuktikan dengan besarnya keberanian dan keaktifan mereka dalam mengikuti setiap materi pembelajaran yang diberikan oleh guru meski pada praktiknya tidak sempurna secara keseluruhan. Namun demikian, pada aspek data lain menunjukkan pula sisi sikap moral (moral feeling) yang cukup berbeda dibandingkan dengan sisi pengetahuan moral (moral knowledge).

Kendala pendidikan nilai moral tersebut diakibatkan oleh adanya pergeseran substansi 
pendidikan kepada pengajaran dengan penyempitan makna pada keutamaan pembinaan nilai moral yang hanya menjadi transfer konten pengetahuan semata. Sebuah diskursus dalam bentuk ide maupun gagasan interaksi yang terbatas pada pengejawantahan program pendidikan yang sudah menjadi ketetapan pemerintah terang-terangan menjadi data kuat sekaligus sebuah acuan orientasi pengembangan nilai moral siswa. Semua ini bermuara pada keterpakuan pembelajaran yang minim pembentukan sikap moralitas dan karakter peserta didik, sebagaimana kondisi suram yang berlaku pada dunia pendidikan yang digambarkan oleh Wiyono, (2012) dan Subur, (2007) meliputi permasalahan umum kultural masyarakat dan dunia pendidikan. Padahal secara tegas Undang-Undang Nomor 20 Tahun 2003 Pasal 40 ayat (2) menekankan bahwa salah satu kewajiban pendidik dan tenaga kependidikan adalah dalam hal menciptakan suasana yang bermakna, menyenangkan, kreatif, dinamis, dan dialogis. Pentingnya pendidikan dan pembelajaran dikemas oleh pendidik dalam konteks menyenangkan dan lain sebagainya lebih jauh adalah untuk menciptakan kebermaknaan ilmu yang dipelajari oleh peserta didik.

Diketahui bahwa antusiasme dan pengetahuan yang tinggi tidak serta-merta menjadikan peserta didik cerdas sepenuhnya dalam bersikap. Ketertarikan yang tinggi terhadap pelajaran dan cara pengajaran pada kenyataannya tidak dapat menjadi jaminan yang cukup resistan secara kualitas terhadap perubahan sikap moralitas. Sikap yang muncul justru lebih kepada motif persepsi peserta didik secara spontan berdasarkan moralitas bawaan dan dominasi perlakuan apa yang mereka dapatkan dari lingkungan intern dan ekstern kehidupan pribadinya sebagai sebuah pembelajaran moral lanjutan. Sementara lingkungan pun tidak cukup bersifat netral melainkan semakin dipengaruhi oleh kebudayaan asing. Kontradiktif ini memperkuat Danim (2015) yang menyajikan narasi dalam bentuk korelasional prinsip pedagogis aktivitas, komunikasi, dan kepribadian yang tidak dapat memisahkan konsep secara bagian per bagian dan konseptual moralitas Komariah (2011) yang mana moralitas dapat berkembang menjadi sebuah kebiasaan atau habituasi dari pengalaman sehari-hari

Memperhatikan hal tersebut, kenyataan bahwa pendidikan jelas memiliki tugas utama yaitu untuk memanusiakan manusia selaras dengan apa yang disampaikan Darmadi (2010) dan Hayati (2017), dalam arti bagaimana potensial moral yang dimiliki seseorang mampu untuk dikembangkan secara simultan. Potensi moral simultan ini dikembangkan oleh sekolah dan proses pembelajaran secara keseluruhan dengan memperhatikan pola-pola moralitas ideal yang patut dimiliki oleh seorang peserta didik sebagai warga negara yang tidak hanya cakap secara kognitif melainkan juga cakap secara kepribadian.

Dengan pengertian bahwa peserta didik tidak dapat begitu saja mengolah setiap informasi menjadi sebuah pertimbangan logis dan keyakinan tinggi atas suatu nilai hingga mereka benar-benar mendapat bimbingan dan arahan yang cukup dari para orang dewasa. Dalam hal ini yaitu kewajiban seorang guru sebagai pendidik untuk menghadirkan dimensi nilai moral dalam bentukan yang mudah dipahami sesuai dengan usia perkembangan psikologis siswa, kemudian mengorelasikan pengetahuan moral dasar tersebut dengan nilai moral sasaran pembentuk sikap. Ini yang dipahami sebagai tindakan moral lebih mendahului pengetahuan moral untuk anak-anak.

Data sebaran nilai moral berikut menggambarkan keyakinan sikap moral (Moral Feeling) siswa SDN Sunyaragi II berdasarkan keberlangsungan kegiatan belajar mengajar yang dapat digambarkan ke dalam 6 (enam) persentase tabel nilai moral feeling meliputi indikator nilai (1) conscience (berhati nurani), (2) self-esteem (percaya diri), (3) Empathy (empati), (4) loving the good (mencintai kebenaran), (5) self-control (kontrol diri), dan (6) humility (kerendahhatian). 


\begin{tabular}{|c|c|c|c|c|c|c|c|c|c|c|}
\hline \multirow{2}{*}{ No. } & \multirow{2}{*}{$\begin{array}{l}\text { Nilai Moral } \\
\text { Feeling }\end{array}$} & \multicolumn{9}{|c|}{ Persentase Indikator Sikap Moralitas Siswa (\%) } \\
\hline & & 1 & 2 & 3 & 4 & 5 & 6 & 7 & 8 & 9 \\
\hline 1. & $\begin{array}{l}\text { Conscience } \\
\text { (berhati nurani) }\end{array}$ & 25,33 & 5,33 & 17,33 & 10,67 & 17,33 & 6,67 & 10,67 & 4,00 & 2,67 \\
\hline 2. & $\begin{array}{l}\text { Self Esteem } \\
\text { (percaya diri) }\end{array}$ & 12,00 & 4,00 & 1,33 & 0,00 & 24,00 & 13,33 & 4,00 & 22,67 & $\begin{array}{l}14 \\
67\end{array}$ \\
\hline 3. & $\begin{array}{l}\text { Empathy } \\
\text { (empati) }\end{array}$ & 29,33 & 6,67 & 9,33 & 8,00 & 16,00 & 9,33 & 12,00 & 6,67 & 6,67 \\
\hline 4. & $\begin{array}{l}\text { Loving the } \\
\text { good } \\
\text { (mencintai } \\
\text { kebenaran) }\end{array}$ & 10,67 & 14,67 & 14,67 & 22,67 & 9,33 & 6,67 & 9,33 & $2,67 \%$ & 9,33 \\
\hline 5. & $\begin{array}{l}\text { Self control } \\
\text { (kontrol diri) }\end{array}$ & 12,00 & 22,67 & 2,67 & 12,00 & 20,00 & 10,67 & 2,67 & 12,00 & 5,33 \\
\hline 6. & $\begin{array}{l}\text { Humulity } \\
\text { (kerendahatian) }\end{array}$ & 16,00 & 21,33 & 10,67 & 22,67 & 4,00 & 12,00 & 5,33 & 4,00 & 4,00 \\
\hline
\end{tabular}

\section{Conscience (Berhati Nurani)}

Nilai moral conscience atau berhati nurani diklasifikasikan ke dalam sejumlah sikap moral pilihan yang sesuai dengan kepribadian dan perkembangan psikologis siswa sekolah dasar. Beberapa nilai tersebut yaitu nilai-nilai kasih sayang dengan kemampuan bersikap mengasihi sesama teman, kemampuan pertimbangan logika dasar dalam mengetahui mana hal atau perbuatan yang benar dan salah. Nilai dorongan serta motivasi untuk senantiasa melakukan perbuatan-perbuatan baik dan bermanfaat, dorongan untuk bersikap, berbicara dan berperilaku jujur dalam segala kondisi, memiliki sisi emosional atau berperasaan peka terhadap kesulitan yang dialami oleh orang sekitar, nilai ketulusan dalam berteman dan menjalin hubungan sosial lainnya. Kemampuan dalam menjaga perkataan sehingga tidak menyakiti dan merendahkan diri sendiri serta orang lain, dan kualitas nilai menjaga perbuatan dan setia terhadap apa kata hati nurani.

Sebaran sikap moral conscience atau berhati nurani menunjukkan hasil yang beragam bergantung dengan keberadaan nilai dominan yang diyakini oleh siswa. Dari tabel di atas diketahui bahwa 3 (tiga) nilai hati nurani yang paling banyak diyakini oleh siswa adalah nilai pengasih dengan jumlah $25,33 \%$, nilai melakukan perbuatan baik dengan jumlah 17, $33 \%$, dan nilai emosional atau berperasaan peka dengan jumlah 17,33\%.
Terpeliharanya kondisi emosional siswa ini sejalan dengan penjabaran kewajiban guru dalam keutamaan strategi pembelajaran dalam pendidikan (Supriadi \& Darmawan, 2013) dimana kondisi tersebut tidak terlepas dari kemampuan dan upaya yang dilakukan oleh guru dalam memenuhi kewajibannya sebagai seorang mentor secara emosional yang menunjukkan ketulusan terhadap siswa sehingga kemudian tercipta rasa aman secara emosional untuk mereka mengembangkan hasrat belajar disamping menekan agresivitas yang mungkin muncul ke permukaan.

Ketiga sebaran nilai tersebut hampir menjadi pilihan nilai mayoritas siswa dengan persepsi umum bahwa mereka memiliki sifat yang mampu mengasihi sesama teman, dermawan, dapat merealisasikan konsep perilaku positif dalam bentuk melakukan suatu perbuatan baik, dan juga kepekaan dalam hubungan sosial pertemanan yang tinggi disamping egoisme usia kanak-kanak yang mereka miliki.

\section{Self-Esteem (Percaya Diri)}

Nilai moral self-esteem atau percaya diri diklasifikasikan ke dalam sejumlah indikator sikap moralitas pilihan yang disesuaikan dengan tingkat pemahaman anak usia sekolah dasar. Beberapa sikap nilai yang diujikan yaitu ketahanan mereka dalam penerimaan perlakuan buruk yang dapat sewaktu-waktu dilakukan oleh teman sepermainan, keyakinan diri bahwa ia memiliki kemampuan hebat pada diri sendiri yang berbeda dengan teman 
yang lain, kepekaan sosial bahwa ia cukup dikenal sebagai seorang pribadi unik dalam lingkungan pertemanannya. Selanjutnya kemampuan dalam menguasai pola hubungan pertemanan, sikap berani untuk senantiasa bertanggung jawab atas semua perbuatan yang dilakukan, nilai sikap gagah berani dalam menghadapi semua permasalahan sosial pertemanan dan lainnya, mampu mengukur kemauan dan kemampuan untuk menggapai segala apa yang dicita-citakan atau bersifat gigih dan tekun, memiliki jiwa yang penuh gairah dan semangat, serta hidup dengan penuh harapan.

Sebaran sikap moral self-esteem atau percaya diri menunjukkan hasil yang beragam bergantung dengan keberadaan nilai dominan yang siswa yakini. Tabel di atas menyuguhkan keberadaan 3 (tiga) nilai percaya diri yang paling banyak mewakili keyakinan siswa yaitu nilai bertanggung jawab dengan jumlah $2 \%$, nilai semangat dengan jumlah $22,67 \%$, dan nilai penuh harapan dengan jumlah 14,67 \%. Sebaran persentase ini berkaitan dengan pemahaman siswa yang lebih banyak mengartikan tanggung jawab sebagai kewajiban diri seorang siswa dalam hal belajar. Selisih kecil yaitu sebesar $1,32 \%$ menunjukkan tingkat semangat siswa dalam menjalani kehidupan sekolah, kehidupan rumah, maupun bermain. Terlepas dari minimnya penyampaian dan pembelajaran nilai moralitas secara runut, terperinci, dan jelas, sikap optimis siswa sesekali masih terlihat mencuat pada beberapa kesempatan pertemuan pembelajaran matematika di kelas dengan karakter rasa ingin tahu yang cukup tinggi terhadap kegiatan pembelajaran. Keterhubungan antar guru dan peserta didik ini dapat terjadi karena adanya kesempatan pengakuan dari keterhubungan keduanya sebagai suatu struktur yang tidak terpisahkan sebagaimana sebuah keluarga (Supriadi \& Darmawan, 2013).

\section{Empathy (Empati)}

Nilai moral empathy atau empati diklasifikasi ke dalam sejumlah alternatif sikap moral pilihan yang sesuai dengan rasa empati pada pemahaman kisaran usia siswa Sekolah Dasar. Pemilihan kata atau diksi dengan memperhatikan aspek tingkat pemahaman mereka dalam melihat dan menanggapi nilai-nilai empati. Beberapa nilai tersebut diantaranya yaitu nilai sikap moralitas penyayang teman, sikap kedermawanan yang dimiliki saat melihat teman yang membutuhkan bantuan atau pertolongan secara materiel dan imateriel, memiliki rasa peka atau rasa iba terhadap kesulitan yang dialami oleh orang lain, memiliki kelembutan hati sehingga menghindari potensi menyakiti sesama, mengutamakan perilaku hormat menghormati terhadap guru dan teman. Selanjutnya memiliki kemampuan sikap untuk tidak membeda-bedakan teman dan bermain dengan semua teman tanpa kecuali, sikap gemar dalam menolong siapa pun yang membutuhkan pertolongan, nilai sikap kemampuan siswa dalam bertoleransi terhadap keberagaman individu antar teman, dan kemampuan untuk senantiasa saling menghargai satu sama lain.

Sebaran sikap moral empathy atau empati menunjukkan hasil yang beragam bergantung dengan keberadaan nilai dominan yang siswa yakini. Dari tabel di atas diketahui bahwa 3 (tiga) nilai empati yang paling banyak menggambarkan kepribadian siswa adalah nilai penyayang dengan jumlah $29,33 \%$, nilai rasa hormat menghormati dengan jumlah 16 $\%$, dan nilai menolong siapa pun dengan jumlah $12 \%$. Tingginya persentase nilai penyayang atau kasih sayang menggambarkan kehidupan psikologis siswa yang secara sosial dapat dikorelasikan dengan kebutuhan akan pengakuan teman-teman sepermainan. Dorongan alamiah pada diri siswa untuk menghimpun banyak pertemanan menjadikan pemberian porsi perhatian dan kasih sayang sangatlah besar. Didukung dengan penghormatan dan kesadaran akan tolong menolong terhadap sesama, jalinan pertemanan yang rawan akan konflik anak kecil menjadi lebih terkendali. Secara keseluruhan, hal ini mengindikasikan bahwa perilaku peserta didik secara sederhana sudah dapat mengasosiasikan keterhubungan antara tindakan yang mereka perbuat berdasarkan pada pertimbangan moralitas konsekuensi 
logis seperti apa yang dapat muncul akibat dari perbuatannya bagi diri dan sesama.

\section{Loving The Good (Mencintai \\ Kebenaran)}

Nilai moral loving the good atau mencintai kebenaran diklasifikasi ke dalam sejumlah alternatif sikap moral pilihan yang sesuai dengan karakteristik nilai moralitas mencintai kebenaran. Nilai-nilai disederhanakan menjadi bentukan sikap yang familiar diketahui dan dialami oleh siswasiswa sekolah dasar. Beberapa nilai sikap moral mencintai kebenaran tersebut diantaranya adalah tidak mudahnya siswa tersinggung dalam hubungan komunikasi dan pertemanan, memiliki pengetahuan mana hal yang benar dan hal yang salah, senantiasa berbicara dan berperilaku jujur dalam kehidupan sehari-hari, senang berdamai dan menghindari konflik antar teman, memiliki kemampuan komunikasi yang baik dalam bentuk berbaik sangka dan tidak menuduh. Selanjutnya mencari tahu kebenaran dengan mengonfirmasi atau mengomunikasikan ulang segala sesuatu hal, memberi keputusan yang masuk akal untuk kepentingan bersama, memiliki nilai kepribadian cerdas, serta memiliki pengetahuan luas yang dipraktikkan menjadi perilaku dan perbuatan yang baik.

Sebaran sikap moral loving the good atau mencintai kebenaran menunjukkan hasil yang beragam bergantung dengan keberadaan nilai dominan yang siswa yakini. Dari tabel di atas diketahui bahwa 3 (tiga) nilai mencintai kebenaran yang paling banyak menggambarkan kepribadian siswa adalah nilai senang berdamai dengan jumlah 22,67 $\%$, nilai berbicara dan berperilaku jujur dengan jumlah $14,67 \%$, dan nilai mengetahui hal yang benar dan salah dengan jumlah 14,67 $\%$. Kesadaran akan pentingnya nilai kedamaian yaitu siswa tidak suka memperpanjang masalah yang terjadi diantara teman. Pemilihan keputusan untuk berdamai menjadi sangat tepat dalam menjalin pertemanan setiap kali terjadi komunikasi yang tidak tepat diantaranya. Kategori nilai mencintai kebenaran dapat menghindarkan seseorang dari perbuatan menyakiti teman dengan berbagai prasangka atau emosi spontanitas anak yang relatif meledak-ledak, dengan pertimbangan bahwa perilaku jujur pun masih perlu untuk ditopang oleh kesadaran penuh atas pemikiran hal yang benar dan salah secara mendasar sehingga tidak terjadi kekeliruan penafsiran dan aplikasi nilai.

Sikap moral mencintai kebenaran bila disandingkan dengan kebutuhan pembelajaran sosial, maka dapat ditarik sebuah kepastian bahwa untuk mengimbangi hasrat alamiah siswa untuk menjalin hubungan sosial hingga mendapatkan peran dalam kelompok bermain dengan teman sebaya seyogianya diimbangi dengan kesadaran pentingnya kecerdasan interpersonal dan intrapersonal. Sehingga tidak berlebihan jika guru difungsikan pula sebagai fasilitator dalam upaya pemecahan masalah dan pengambilan keputusan permasalahan yang dialami siswa.

\section{Self-Control (Kontrol Diri)}

Nilai moral self-control atau kontrol diri dijelaskan ke dalam sejumlah alternatif nilai perilaku utama yang sering dialami oleh siswa dalam kehidupan sehari-harinya. Nilai ini pulalah yang sering bersinggungan dengan kehidupan sosial siswa baik di lingkungan keluarga, sekolah, maupun masyarakat. Penjabaran nilai moralitas kontrol diri ke dalam sikap moral bagaimana siswa mampu untuk mengendalikan diri dengan tidak mudah merasa tersinggung, kemampuan untuk menjaga hubungan sosial pertemanan dan menghindari pertengkaran, hati yang senantiasa berbaik sangka dan tidak suka menuduh dengan gegabah, kemampuan menahan diri dari godaan untuk berperilaku atau melakukan hal-hal yang buruk yang dapat menyakiti atau merugikan diri dan orang lain. Selanjutnya memiliki pemahaman dan dapat berperilaku sabar, memiliki kemampuan dalam berdisiplin, nilai tidak puas diri dengan tetap santun, senantiasa menjaga semangat dalam diri, dan mengalah untuk menghindari pertengkaran atau permusuhan antar teman yang sia-sia.

Sebaran sikap moral self-control atau kontrol diri menunjukkan hasil yang beragam bergantung dengan keberadaan nilai dominan yang siswa yakini. Dari tabel di atas diketahui bahwa 3 (tiga) nilai kontrol diri yang paling 
banyak menggambarkan kepribadian siswa adalah nilai menghindari pertengkaran dengan jumlah 22,67 \%, nilai kesabaran dengan jumlah $20 \%$, dan tidak mudah tersinggung, tahan godaan dan perilaku buruk, dan bersemangat yang masing-masing memiliki jumlah $12 \%$. Data keyakinan siswa dalam menghindari pertengkaran menunjukkan kemampuan sikap kontrol diri menjaga harmonisasi sosial hubungan antar teman. Persentase yang muncul secara bersamaan dalam hal nilai sikap tidak mudah tersinggung, tahan atau pantang berperilaku buruk, dan bersemangat sangat luar biasa menggambarkan heterogenitas pemahaman atas kontrol diri, sehingga aplikasi pada dunia anak didik dapat beragam dan luas makna.

Keberagaman sikap moral kontrol diri siswa di atas merupakan bagian khusus penjabaran dari kecakapan berinteraksi yang erat hubungannya dengan kemampuan berkomunikasi dan bekerja sama dengan orang lain dalam kecakapan partisipatoris. Kemampuan berinteraksi meliputi kemampuan-kemampuan berikut yakni "(1) kemampuan untuk mendengarkan dengan penuh perhatian, (2) kemampuan untuk bertanya dengan efektif, (3) kemampuan untuk mengutarakan pikiran dan perasaan, (4) kemampuan untuk mengelola konflik melalui mediasi, kompromi, dan kesepakatan" (Mujtahidin, 2017, hal. 46).

\section{Humility (Kerendahan hati)}

Nilai moral humility atau kerendahan hati dijelaskan ke dalam kategorisasi sikap moral sederhana sesuai dengan tingkat pemahaman siswa dalam memersepsikan makna dari kerendahan hati. Beberapa sikap moral tersebut diantaranya yaitu indikator kepemilikan sifat-sifat keterbukaan komunikasi siswa terhadap lingkungan sekitar terutama kepada orang tua, kemampuan siswa untuk tidak membeda-bedakan teman yaitu memiliki kehendak untuk bermain dengan semua tanpa melakukan perbuatan bullying atau diskriminasi. Selanjutnya sikap berani dan bertanggung jawab untuk mengakui dan menyesali kesalahan yang telah diperbuat, dimilikinya sifat dan sikap pengasih yang mudah dalam memaafkan, tingginya rasa hormat menghormati antar sesama manusia tanpa terkecuali. Selain itu juga, memiliki tata-krama atau adab yang sopan dalam bertindak dan berperilaku, nilai reflektif kesadaran atas batasan kemampuan diri, kemampuan bertanggung jawab atas segala keputusan yang diambil dan perilaku yang diperbuat, serta keinginan untuk senantiasa menjadi pribadi yang lebih baik.

Sebaran sikap kerendahan hati menunjukkan hasil yang beragam bergantung dengan keberadaan nilai dominan yang siswa yakini. Dari tabel di atas diketahui bahwa 3 (tiga) nilai kerendahan hati yang paling banyak menggambarkan kepribadian siswa adalah nilai pemaaf dengan jumlah 22,67\%, nilai tidak membeda-bedakan teman dengan jumlah 21,33\%, dan nilai keterbukaan dengan jumlah $16 \%$. Data nilai pemaaf yang memiliki persentase lebih tinggi disusul dengan nilai-nilai lainnya memiliki runtun kesesuaian dimana dari sikap nilai sebelumnya yang diyakini oleh siswa, siswa enggan untuk bertengkar, mereka menghindari hal tersebut meski kemungkinan untuk bertengkar kecil dengan teman selalu ada, dan justru lebih senang untuk berdamai.

Data-data yang tersaji menjadi penguat bahwa super ego anak mampu dikendalikan dengan bantuan didikan utama orang tua dan guru dalam memproyeksikan tujuan hidup, cara pencapaian, dan pengukuran kualitas perubahan perilaku peserta didik secara moralitas (Helaluddin \& Syawal, 2018). Bantuan tersebut sangat penting dilakukan secara personal untuk menangani tindakan berlebih yang muncul dari peserta didik. Sehingga pada titik tertentu, super ego yang dimiliki oleh peserta didik secara alamiah dapat sangat membantu mereka dalam menentukan mana perbuatan yang baik dan tidak baik untuk dilakukan, terutama berkaitan dengan pertimbangan moralitas yang sering dihadapi peserta didik dalam hubungan dan komunikasi sosial dengan teman dan lingkungan sekitar.

\section{Simpulan}

Kelangsungan aktivitas pembelajaran di SDN Sunyaragi II Cirebon secara umum berjalan sangat baik secara konsep transfer keilmuan, namun tidak berdasarkan 
pengembangan sikap moral, dimana keberadaan pendidikan karakter menjadi hal yang bias makna karena kurangnya daya analisis terhadap nilai yang menjadi keyakinan siswa, dominasi materi tematik yang belum sepenuhnya dipahami oleh guru dan siswa, serta rendahnya penguatan nilai moral atas semua kegiatan pembelajaran. Nilai moralitas kemudian hanya mendapatkan perhatian seadanya, dengan bantuan aktivitasaktivitas pada buku guru dan buku siswa. Dominasi nilai sikap moral siswa bervariasi tergantung kepada kategorisasi pemahaman dan keyakinan nilai bawaan serta keyakinan nilai yang dipelajari bersama di sekolah.

\section{Referensi}

Ali, M. (2009). Pendidikan untuk pembangunan nasional. Jakarta: Grasindo.

Danim, S. (2015). Pedagogi, andralogi, heuralogi,. Bandung: CV Alfabeta.

Darmadi, H. (2010). Pengantar pendidikan kewarganegaraan. Bandung: Alfabeta.

Hayati, A. A. (2015). Kajian pendidikan nilai moral melalui program living values activities dalam pengembangan karakter siswa di SMA Plus Muthahhari Bandung. Civicus: Jurnal Pendidikan Kewarganegaraan, 19(2), 115-133.

Hayati, A. A. (2017). Manifestasi konsep living values education pada materi hak dan kewajiban warga negara melalui kegiatan konservasi mangrove mahasiswa Unswagati Cirebon. In Prosiding Konferensi Nasional Kewarganegaraan (KNKn) III, "Peneguhan Jiwa Profetik-Patriotik Warga Negara Dalam Merespon Dinamika Ke-Indonesia-an dan Kemanusiaan (hal. 152-158). Yogyakarta: Universitas Ahmad Dahlan Yogyakarta.

Helaluddin, \& Syawal, S. (2018). Psikoanalisis Sigmund Freud dan Implikasinya dalam Pendidikan.
Komariah, K. St. (2011). Model pendidikan nilai moral bagi para remaja menurut perspektif Islam. Jurnal Pendidikan Agama Islam - Ta'lim, 9(1), 45-54.

Mujtahidin. (2017). Civic education di sekolah. Penguatan pendidikan karakter melalui pembelajaran PKn ang inovatif dan efektif. Surabaya: Pustaka Radja.

Mulyana, R. (2004). Mengartikulasikan pendidikan nilai. Bandung: Alfabeta.

Ruyadi, Y. (2010). Model pendidikan karakter berbasis kearifan budaya lokal ( penelitian terhadap masyarakat adat Kampung Benda Kerep Cirebon Provinsi Jawa Barat untuk pengembangan pendidikan karakter di sekolah ). In The 4th International Conference on Teacher Education (hal. 576-594). Bandung: Universitas Pendidikan Indonesia.

Sanusi, A. (2016). Pendidikan untuk kearifan, mempertahankan kembali sistem nilai, belajar, dan kecerdasan. Bandung: Penerbit Nuansa.

Subur. (2007). Pendidikan nilai: Telaah tentang model pembelajaran. Insania, Jurnal Pemikiran Alternatif Pendidikan, 12(1), 1-10.

Supriadi, D., \& Darmawan, D. (2013). Komunikasi pembelajaran. Bandung: PT Remaja Rosdakarya.

Wiyono, H. (2012). Pendidikan karakter dalam bingkai pembelajaran di sekolah. Jurnal Ilmiah Civics, II(2). 